\title{
Pediatric Nurses Knowledge, Awareness and Attitude towards Application of Stem Cells Therapy in Children
}

\author{
Amira Mohammed Saed Mohammed Khali, and Sabah Mohammad El Sayed \\ Sharshor ${ }^{2}$ \\ Pediatric Nursing Department, Faculty of Nursing Tanta University, Egypt
}

\begin{abstract}
:
Background: Stem cell transplantation is a life saving procedure for a number of malignant and nonmalignant life threatening diseases.

Aim of the study: to assess nurses' knowledge, awareness and attitude toward application of stem cells therapy in children.

Material and Methods:

Research design: Descriptive study design was utilized in this study. This study was conducted at Pediatric Intensive Care Unit and Pediatric Hematology and Oncology Department Tanta University Main Hospital, Egypt. All nurses who work in pediatric intensive care unit and hematological department Hospital, Tanta University, Egypt, were included in the study. Three tools were used by the researchers to obtain the necessary data.
\end{abstract}

Tool I: Structured interview sheet to assess nurses' knowledge about stem cell therapy.

Tool II: Nurses stem cell therapy awareness assessment sheet.

Tool III: Nurses attitude towards stem cell therapy assessment sheet.

Results: Nurses' Knowledge about stem cells are lacking, in adequate knowledge represented by $69 \%$ and they identified from their point of view that the costs of the stem cells, policies and procedures are barriers of conducting such new technology in their hospitals.

Conclusion and Recommendations: Nurses' level of knowledge about stem cells is in adequate and this indicates the necessity of creation of educational programs and continual training with the use of stem cells. Also nurses must be equipped to know the approved standards and understanding it.

Keywords: Nurses Knowledge, Awareness, Attitude, application of Stem Cells Therapy, children

\section{Introduction}

A stem cell can generally be defined as "clonal, self renewing entity that is multipotent and thus can generate several differentiated cell types. In other words, stem cell is a cell that produces anidentical copy of it self countless times correctly when it divides. This same stem cell can differentiate or become more than one specific cell type. The capacity for "selfrenewal" allows for a potential continuous source of cells. The ability to produce offspring cellsthat can differentiate allows for more tissues to obtain new cells whe $\mathrm{n}$ dead cells need tobe replaced or when damage tissues need to be repaired. These two broad characteristicsof al 1 stem cells, selfrenewal and differentiation, provide the potential ability to use thesestem cells in many different therapeutic treatments. (1)

A stem cell is a cell that can be come establishes in an appropriate growing environment, has the ability multiply, can produce cell types that continue to differentiate and renew itself or ensure the continuation of its own population and can regenerate tissue with functional damage. Stem cells are cells found in all multi cellular organisms. They are characterized by the ability to renew themselves through mitotic cell division and differentiate into a diverse range of specialized cell types. The two broad types of mammalian stem cells are: embryonic stem cells that are isolated from the inner cell mass of blasto-cysts, and adult stem cells that are found in adult tissues. In a developing embryo, stem cells can differentiate into all of the specialized embryonic tissues. In adult organisms, stem cells and progenitor cells act as a repair system for the body.(2)

There are different types of stem cells are examined, however, more specific characteristics that define each specific stem cell type become apparent. The three broad types of stem cells are embryonic, umbilical cord blood, and adult stem cells. Stem cell transplantation is a lifesaving procedure for a number of malignant and non-malignant life threatening diseases. More than 40,000 stem cell transplants are being performed annually in the world.(3) Stem cells, which have been used for a period of time in the treatment of leukaemia and other types of cancer, have recently started to be used in medicine development, and this progress offer hope for the treatment of diabetes, cardiovascular and neuro-generative diseases, but the applications are still unproven.(4) 
Awareness levels among the healthcare providers when increased, especially the pediatric nurses about the concept and strong legalised and less commercialised environment can work positively towards making stem cell banking an integral part of healthcare. Hence, the researchers felt the need to assess the knowledge and attitude of pediatric nurses on stem cell applications. (5) Paediatric Nurses need to understand stem cell sources so they can enter the debate on this issue. Discussions are often intense because of the different positions held by scientific, religious, social and political sources. Nurses need to equip themselves with accurate information, using the international Council of Nursing Code of Ethics for Nurses (6)and their own ethical decision-making processes. They can then make decisions for themselves about the efficacy of stem cell research and then become important sources of knowledge and information to help others understand and debate the direction of this scientific breakthrough.(7)

\section{Aim of the study:}

Aim of this study is to assess the nurses' knowledge, awareness and attitude towards application of stem cells therapy in children.

\section{Materials and Methods Materials}

Study Design: The study design was descriptive cross sectional design.

Setting: The study was conducted at Paediatric Intensive Care Unit \&Haematology and Oncology Department, Main Hospital, Tanta University, Egypt.

Sample: The study was conducted from October to December 2015 for a period of 3 months. During the 3 months period of the study, 50 nurses were interviewed from the previously mentioned settings. Subjects were selected using convenience sampling.

Tools of the study: Three tools were used by the researchers to obtain the necessary data.

Three tools were used by the researchers to obtain the necessary data.

Tool I: Structured interview sheet. It was used to assess nurses' knowledge about stem cell therapy. It comprised from two parts:

Part I: It included student socio-demographic characteristics as age, and education, years of experience, and attendance to workshop about stem cell.

Part II: It included close ended questions to assess nurses' knowledge about stem cell therapy in relation to definition of stem cells, sources of information about stem cells, stem cell classification, sources of stem cell, application of stem cells in paediatric, and importance of stem cell.

\section{Scoring system of nurses' knowledge:}

The knowledge questionnaire included (7) questions. The total score of all questions was (16 degree). Each correct answer was assigned as score of "one" and wrong answer or don't know as score of "zero".

Tool II: Nurses stem cell therapy awareness assessment sheet. It was used to assess nurses' awareness regarding presence of stem cells banks in Egypt, and Egypt Council of Medical Research guidelines regarding Stem Cells.

Tool III: Nurses attitude towards stem cell therapy assessment sheet. It was used to assess nurses' attitude towards stem cells preservation, barrier in seeking stem cells treatment, preference to attend any workshop / conference, gaining knowledge about stem cells, and Stem cells research can be development in the future. The participants completed the question airemanually in a space provided by their service in the presence of the researchers and after completion they handed it back to them, they requested to complete all sections of this questionnaire.

\section{Methods}

\section{Administrative design}

Before the conduction of the pilot study as well as the actual study, an official permission and consent were obtained from the dean of the Faculty of Nursing, as well as the Director of at paediatric intensive care unit \& haematological department Hospital, Tanta University, Egypt.

\section{Ethical Consideration:}

The study protocol was approved by pertinent research and ethical committees. Informed written consent was taken from every nurse before inclusion in the study. No health hazards were present. Participants 
were as sured that all their data are highly confidential, anonymity was also as sured through as signing a number for each nurse instead of names to protect their privacy. Data was only available to the researchers and the participants.

\section{Field work of the study}

An official permission was obtained from the research ethical committee of the Department of paediatric intensive care unit \& haematological department Hospital, Tanta University, Egypt and Faculty of Nursing, Tanta University to commence and approve this study. Participants nurses were recruited from the paediatric intensive care unit \& haematological department as it provided a list of nurses who were likely to be current practitioners in the previously mentioned settings, Each nurse were interviewed individually after taking their consent to participate in the study and given an explanation about the nature of the study by the investigators. Data included assessment of the nurses' knowledge regarding stem cells. Data collection occurred over a 3-month period between October and December 2015, the time required to fill the questionnaire was from 20-30 minutes.

\section{Statistical Analysis:}

The data were coded, entered and analysed using SPSS (version 20). Descriptive statistics (frequency numbers and Percentages) identified demographic characteristics and nurses responses to the questionnaire. The mean and standard deviation were calculated for total nurses, knowledge. Paired $t$ tests were used to analyse the relationships; statistical significant was set at $\mathrm{P}$ value $<0.05 \%$. Correlation between knowledge and demographic characteristics was tested suing Pearson Test.

\section{Results}

Table(1) represents the Socio-demo graphic characteristics of the studied nurses. The studied sample consisted of 50 nurses, the gender of all of them were females. Participant nurses 'ages were primarily between 19 And 58 Years of age. As regards the current nursing role in the paediatric intensive care unit \& haematological department Hospital, most of the nurses (96.0\%) were practice nurses who were provided care for children and the remaining $(4.0 \%)$ were supervisor's nurses. Bachelor's degree represented $48.0 \%$ of the studied sample in the paediatric intensive care unit, while $80.0 \%$ of them had diploma degree in the haematological department. Regarding years of experience, the table shows that $76.0 \%$ of nurses in PICU unit had less than 10 years of experience and $80.0 \%$ in haematology unit had from 10 to 20 years. The present study found that all of them $(100.0 \%)$ need additional information about stem cell in the form of training courses, educational program.

Table(2) shows percent distribution of nurses knowledge about stem cells therapy, it was observed that approximately two third $(68.0 \%)$ of nurses in PICU and the vast majority $(92.0 \%)$ of the participant nurses' in haematology unit were not know the meaning of the stem cells. Sources of nurses information about stem cells were under graduated training, books, internet, and conferences with percent $8.0 \%, 8.0 \%, 8.0 \%$, 4.0\% respectively in PICU While the source of information for $8.0 \%$ of nurses in the haematology unit was internet. As regards the nurses' knowledge about stem cells classification, it was observed that $40.0 \%$ and 92.0\% of them in PICU and haematological department don't know stem cells classification respectively. Furthermore, 36.0\% of nurses reported that the source of collected blood is placental, 32.0\%ofthe nurses knows all sources of collected stem cells, and 32.0\% of them don't know sources of collected stem cell sin PICU while the majority of them $(92.0 \%)$ don't know the source of collected stem cells and the rest of them $(8.0 \%)$ reported that the source of collected stem cells isumbilical cord in the haematology department. This table also illustrated that nurse's knowledge about importance of stem cells; the vast majority of them $(80.0 \%, 92.0 \%)$ don't know the importance of stem in both settings respectively.

Figure (1) shows percent distribution of nurses' knowledge about stem cells therapy application Slightly less than half of the nurses in PICU stated that stem cells therapy application include blood disorders, heart diseases, diabetes, and burn while 55.0\% were not know stem cells therapy application. On the other hand, the majority of nurses in haematology unit did not know stem cells therapy application.

Table (3) Presents Percent Distribution of Nurses awareness about stem cells therapy, it was observed that two third of the nurses $(60.0 \%)$ reported that they don't aware with the presence of stem cells banks in Egypt in both setting respectively. As regarding nurses' awareness with Egypt Council of Medical Research guidelines regarding Stem Cells, it was reported that about half of them (56.0\%) aware with it in PICU while $72.0 \%$ of the participant nurses don't aware in haematology department.

Table (4) illustrate Percent Distribution of nurses attitude to stem cells therapy, it was reported that attitude of two third of the nurses (64.0\%)toward Stem cells preservation was negative in PICU whereas the attitude of $60.0 \%$ of them in haematology department was positive attitude. As regarding nurses attitude to barrier in seeking stem cells treatment, it was noted that about half of the nurses in both settings $(52.0 \%, 40 \%)$ reported that high cost is the main barrier. Regarding preference to attend any workshop/conference about stem 
cells treatment, it was observed that most of them $(92.0 \%)$ prefer that. Moreover, $44.0 \%$ of nurses in both groups prefer to gaining knowledge about stem cells in their curriculum. In relation to Stem cells research, $80.0 \%, 60.0 \%$ of nurses in PICU and haematology department view that it can be developed in future under supervision of Public-Private Sector.

Table (5) shows mean total nurses knowledge, awareness and attitude to stem cells therapy in both settings, it was observed that the mean total nurses' knowledge was $10.4 \pm 5.52$ and $3.6 \pm 2.6$ in PICU and haematology department respectively. Moreover, the mean total nurses' awareness was $76 \pm 0.870,48 \pm 0.870$ in PICU and haematology department respectively. Regarding the mean total nurses attitude, it was 5.3 \pm 0.95 , $5.4 \pm 1$ in PICU and haematology department respectively.

Table (6) shows the relationship between total nurses' knowledge, awareness, attitude and sociodemographic characteristics of the studied nurses. The table illustrate that there was no statistical significant correlation between nurses' knowledge, awareness, attitude and socio-demographic characteristics in both setting. Moreover, there was statistical significant correlation between PICU nurses' total awareness and attitude with their age whereas; there was no statistical significant correlation between haematology nurses' total awareness and attitude with their socio-demographic characteristics.

Table(1): Percent Distribution of the Studied Nurses according to their Socio-Demographic Characteristics.

\begin{tabular}{|c|c|c|c|c|}
\hline \multirow[t]{2}{*}{ Socio-demographic characteristics } & \multicolumn{2}{|c|}{ PICU Nurses } & \multicolumn{2}{|c|}{ Haematology Nurses } \\
\hline & $\mathrm{NO}=25$ & $\%$ & $\mathrm{NO}=25$ & $\%$ \\
\hline $\begin{array}{l}\text { Age } \\
-<30 \\
-30-40 \\
->40 \\
\end{array}$ & $\begin{array}{l}15 \\
9 \\
1\end{array}$ & $\begin{array}{l}60.0 \\
36.0 \\
4.0\end{array}$ & $\begin{array}{l}10 \\
13 \\
2\end{array}$ & $\begin{array}{l}40.0 \\
52.0 \\
8.0\end{array}$ \\
\hline $\begin{array}{l}\text { Level of education (qualification) } \\
\text { Diploma } \\
\text { Institute } \\
\text { Bachelor }\end{array}$ & $\begin{array}{l}4 \\
9 \\
12 \\
\end{array}$ & $\begin{array}{l}16.0 \\
36.0 \\
48.0\end{array}$ & $\begin{array}{l}20 \\
5 \\
0\end{array}$ & $\begin{array}{l}80.0 \\
20.0 \\
0.0\end{array}$ \\
\hline $\begin{array}{l}\text { Current nursing role:- } \\
\text { Supervisor nurse } \\
\text { Practice nurse }\end{array}$ & $\begin{array}{l}1 \\
24\end{array}$ & $\begin{array}{l}4.0 \\
96.0\end{array}$ & $\begin{array}{l}1 \\
24\end{array}$ & $\begin{array}{l}4.0 \\
96.0\end{array}$ \\
\hline $\begin{array}{l}\text { Yearsofexperience: } \\
-<10 \text { years } \\
-10-20 \text { years }\end{array}$ & $\begin{array}{l}19 \\
6\end{array}$ & $\begin{array}{l}76.0 \\
24.0\end{array}$ & $\begin{array}{l}5 \\
20\end{array}$ & $\begin{array}{l}20.0 \\
80.0\end{array}$ \\
\hline $\begin{array}{l}\text { Attendance to workshop about stem cell } \\
\text { Yes } \\
\text { No }\end{array}$ & $\begin{array}{l}1 \\
24\end{array}$ & $\begin{array}{l}4.0 \\
96.0\end{array}$ & $\begin{array}{l}0 \\
25\end{array}$ & $\begin{array}{l}00.0 \\
100.0\end{array}$ \\
\hline $\begin{array}{l}\text { Need additional information:- } \\
\text { Needed } \\
\text { Not needed }\end{array}$ & $\begin{array}{l}25 \\
0 \\
\end{array}$ & $\begin{array}{l}100.0 \\
00.0\end{array}$ & $\begin{array}{l}25 \\
0 \\
\end{array}$ & $\begin{array}{l}100.0 \\
00.0\end{array}$ \\
\hline
\end{tabular}

Table (2):-Percent Distribution of Nurses Knowledge about Stem Cells Therapy

\begin{tabular}{|l|l|l|l|l|}
\hline Nurses knowledge about & \multicolumn{2}{l|}{ PICU Nurses } & Haematology Nurses \\
\cline { 2 - 5 } stem cells therapy & NO=25 & $\%$ & NO=25 & $\%$ \\
\hline Definition of stem cells & & & & \\
Know & 8 & 32.0 & 2 & 8.0 \\
Don't know & 17 & 68.0 & 23 & 92.0 \\
\hline Sources of information & & & & \\
about stem cells & 2 & 8.0 & 0 & 0.0 \\
Undergraduate training & 3 & 8.0 & 2 & 8.0 \\
Internet & 2 & 8.0 & 0 & 0.0 \\
Books & 1 & 4.0 & 0 & 0.0 \\
Conference/Symposium/Se & 17 & 68.0 & 23 & 92.0 \\
minar & & & & \\
No information source & & & & \\
\hline Stem cell classification & & & \\
\hline
\end{tabular}




\begin{tabular}{|l|l|l|l|l|}
\hline Embryonic Stem cells & 6 & 24.0 & 0 & 0.0 \\
Adult Stem cells & 0 & 0.0 & 0 & 0.0 \\
Embryonic and adult Stem & 9 & 36.0 & 2 & 8.0 \\
cells & 10 & 40.0 & 23 & 92.0 \\
Don't know & & & & \\
\hline Sources of stem cell & & 36.0 & 0 & 0.0 \\
collection & 9 & 0.0 & 2 & 8.0 \\
Placenta & 0 & 0.0 & 0 & 0.0 \\
Umbilical cord & 0 & 0.0 & 0 & 0.0 \\
Amniotic fluid & 0 & 0.0 & 0 & 0.0 \\
Aborted fetus & 0 & 0.0 & 0 & 0.0 \\
Surplus to IVF inoculate & 0 & 32.0 & 0 & 0.0 \\
& 8 & 32.0 & 23 & 92.0 \\
The rapeuticcloning & 8 & & & \\
& & & & \\
All of the above & & & & 8.0 \\
& & 20.0 & 2 & \\
Don't know & 5 & 80.0 & 23 & \\
\hline Importance of stem cell & & & & \\
Know & 20 & & \\
Don't know & & & & \\
\hline
\end{tabular}

Figure (1) Percent Distribution of Nurses' Knowledge about Stem Cells Therapy Application

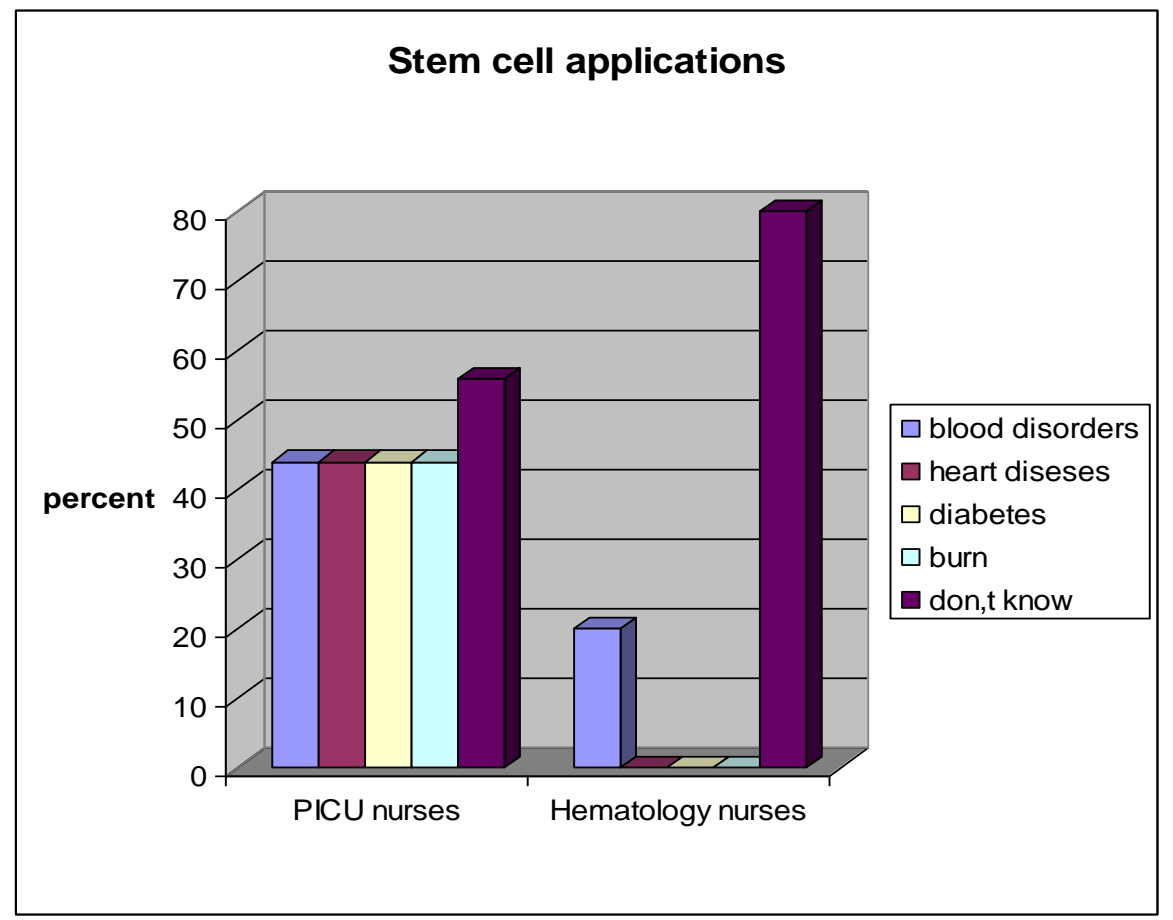

Table (3):-Percent Distribution of Nurses awareness about Stem Cells Therapy

\begin{tabular}{|c|c|c|c|c|}
\hline \multirow[t]{2}{*}{ Nurse awareness about stem cells therapy } & \multicolumn{2}{|c|}{ PICU Nurses } & & \multirow{2}{*}{$\begin{array}{l}\text { Haematology } \\
\text { Nurses } \\
\% \%\end{array}$} \\
\hline & $\mathrm{NO}=25$ & $\%$ & $\mathrm{NO}=25$ & \\
\hline $\begin{array}{l}\text { Presence of stem cells banks in Egypt } \\
\text { Yes } \\
\text { No } \\
\text { Don't aware }\end{array}$ & $\begin{array}{l}3 \\
7 \\
15\end{array}$ & $\begin{array}{l}12.0 \\
28.0 \\
60.0\end{array}$ & $\begin{array}{l}2 \\
8 \\
15\end{array}$ & $\begin{array}{l}8.0 \\
32.0 \\
60.0\end{array}$ \\
\hline $\begin{array}{l}\text { awareness of Egypt Council of Medical } \\
\text { Research guidelines regarding Stem Cells } \\
\text { Yes } \\
\text { No }\end{array}$ & $\begin{array}{l}11 \\
14 \\
\end{array}$ & $\begin{array}{l}44.0 \\
56.0\end{array}$ & $\begin{array}{l}7 \\
18 \\
\end{array}$ & $\begin{array}{l}28.0 \\
72.0\end{array}$ \\
\hline
\end{tabular}


Pediatric Nurses Knowledge, Awareness and Attitude towards application of Stem Cells Therapy in

\begin{tabular}{|l|l|l|l|l|}
\hline Total Nurse awareness & & & & \\
Aware & 3 & 12.0 & 1 & 4.0 \\
Notaware & 22 & 88.0 & 24 & 96.0 \\
\hline
\end{tabular}

Table (4):-Percent Distribution of Nurses Attitude to Stem Cells Therapy

\begin{tabular}{|l|l|l|l|l|}
\hline \multirow{2}{*}{ Nurses attitude to stem cells therapy } & \multicolumn{2}{l|}{ PICU Nurses } & \multicolumn{2}{l|}{ Haematology Nurses } \\
\cline { 2 - 5 } & NO=25 & $\%$ & NO=25 & $\%$ \\
\hline Stem cells preservation & & & & \\
Yes & 16 & 36.0 & 15 & 60.0 \\
No & 9 & 64.0 & 10 & 40.0 \\
\hline Barrier in seeking stem & & & & \\
cells treatment & 13 & 52.0 & 10 & 40.0 \\
High cost & 5 & 20.0 & 10 & 40.0 \\
Lack of awareness & 7 & 28.0 & 5 & 20.0 \\
Lack of sufficient knowledge & & & & \\
\hline Preference to attend any workshop/conference & 23 & 92.0 & 23 & 92.0 \\
Yes & 2 & 8.0 & 2 & 8.0 \\
No & & & & \\
\hline Gaining knowledge about stem cells by: & 6 & 24.0 & 4 & 16.0 \\
More real life training & 8 & 32.0 & 10 & 40.0 \\
Short courses & 11 & 44.0 & 11 & 44.0 \\
Included in the curriculum & & & & \\
\hline Stem cells research can be developed in future under & & & & \\
supervision of:- & & 16.0 & 5 & 20.0 \\
Public Sector initiatives & 4 & 4.0 & 5 & 20.0 \\
Private Sector initiatives & 1 & 80.0 & 15 & 60.0 \\
Public-Private Sector initiatives & 20 & & & \\
\hline
\end{tabular}

Table (5):-Mean Total Nurses Knowledge, Awareness and Attitude to Stem Cells Therapy.

\begin{tabular}{|l|l|l|l|}
\hline $\begin{array}{l}\text { Total Nurses knowledge, awareness and } \\
\text { attitude to stem cells therapy }\end{array}$ & $\begin{array}{l}\text { PICU Nurses } \\
\text { NO }=25\end{array}$ & $\begin{array}{l}\text { Haematology } \\
\text { Nurses } \\
\text { NO }=25\end{array}$ & p-value \\
\cline { 2 - 4 } & Mean \pm SD & Mean \pm SD & \\
\hline Total Nurses knowledge & $10.4 \pm 5.52$ & $3.6 \pm 2.6$ & $.000 *$ \\
\hline Total Nurses awareness & $.76 \pm 0.870$ & $.48 \pm 0.870$ & .258 \\
\hline Total Nurses attitude & $5.3 \pm 0.95$ & $5.4 \pm 1$ & .694 \\
\hline
\end{tabular}

Table (6):- The Relationship between Total Nurses Knowledge, Awareness, and Attitude and SocioDemographic Characteristics of the Studied Nurses.

\begin{tabular}{|c|c|c|c|c|c|c|}
\hline \multirow{2}{*}{$\begin{array}{l}\text { Total Nurses knowledge, } \\
\text { awareness and attitude } \\
\text { PICU Nurses Total knowledge }\end{array}$} & \multicolumn{2}{|c|}{ Age in years } & \multicolumn{2}{|c|}{ Years of experience } & \multicolumn{2}{|c|}{ Education } \\
\hline & $\begin{array}{l}P \\
0.277\end{array}$ & $\begin{array}{l}\mathrm{R} \\
0.226\end{array}$ & $\begin{array}{l}P \\
0.667\end{array}$ & $\begin{array}{l}\mathrm{R} \\
0.091\end{array}$ & $\begin{array}{l}\mathrm{P} \\
0.339\end{array}$ & $\begin{array}{l}\mathrm{R} \\
0.200\end{array}$ \\
\hline $\begin{array}{l}\text { Hematology Nurses Total } \\
\text { knowledge }\end{array}$ & .517 & .136 & 0.577 & 0.117 & .751 & .067 \\
\hline PICU Nurses Total awareness & $.039 *$ & 0.416 & 0.389 & 0.180 & 0.212 & 0.225 \\
\hline $\begin{array}{l}\text { Hematology Nurses Total } \\
\text { awareness }\end{array}$ & 0.087 & 0.349 & 0.074 & 0.363 & 0.511 & 0.138 \\
\hline PICU Nurses Total attitude & $0.007 *$ & 0.523 & 0.504 & 0.140 & 0.383 & 0.182 \\
\hline $\begin{array}{l}\text { Hematology Nurses Total } \\
\text { attitude }\end{array}$ & 0.933 & 0.180 & 0.636 & 0.100 & 0.569 & 0.120 \\
\hline
\end{tabular}




\section{Discussion}

Stem cells have tremendous promise to help us understand and treat a range of diseases, injuries and other health-related conditions. Their potential is evident in the use of blood stem cells to treat diseases of the blood, a therapy that has saved the lives of thousands of children with leukaemia; and can be seen in the use of stem cells for tissue grafts to treat diseases or injury to the bone, skin and surface of the eye. Important clinical trials involving stem cells are underway for many other conditions and researchers continue to explore new avenues using stem cells in medicine $(8,9)$.

The nursing power providers of Tanta university hospitalis excellent professionals because most of them is graduated from the Faculty of Nursing and the Technical Institute of Nursing, Tanta University, Egypt. So it is a valuable idea to recommend the initiation of a stem cells bank in collaboration with the hematology unit.

When exploring the knowledge of the nurses about the stem cells, an important element highlighted in this study is the lack nurse's knowledge in basic clinical information regarding stem cells.

The present study findings found that approximately two third of the studied nurses in PICU and the majority $(92.0 \%)$ of participant nurses' in haematological unit had no knowledge about stem cell sand the first source of information was under-graduated training, books and internet. when comparing the results of the present study with a study done by Hatzistilli et. Al (10) to examine the health professionals' knowledge and attitude towards the stem cells donation in Greec and concluded that, the knowledge regarding the donation of stem cells was evaluated to be $15.6 \%$ of the respondents regarding the collection's, storage and use of stem cells, furthermore, no statistical significant relationship has been found between the percentage of correct answers and years of experience.

It is more interestingly that vast majority of the studied nurses of this study wanted additional information about the subject of stem cells this is due to the lack of their knowledge, thus this result is quietly encouraging because it was shown that the participants positively in need for further information on that subject they didn't know enough about it and preferred not to neglect. Similar findings by Katzet.al,(11) who found in their study that the respondents from other countries had a similar view point thus the respondents considered that the information provided by the health care professionals was in sufficient so additional information was wanted.

As regards then urses knowledge about the source of stem cells collection, the presents study showed that some nurses reported the source of collected blood is placental while other nurses knew the source of collected blood is placental, umbilical, amniotic fluid, aborted fet us, surplus to IVF inoculate and the rapeutic cloning, while more than one third of the sample of nurses didn't know about the source of stem cells collection. Many studies supported the drawing of the blood from the umbilical vein into the collection bags by using a closed system collection kit (12).

Concerning the nurses' awareness about the presence of stem cells banks in Egypt, few of the nurses reported that they knew the presence of stem cells banks as a type of storage while one quarter of them reported that no stem cells bank present in Egypt and two third of the participant nurses didn't know anything about the presence of stem cells banks in Egypt. These results are disagreed with the results of a study of Screnci et.al,

(12) who study donating stem cells to a public bank or storing in a private bank, the awareness and preferences of blood donors they found that, few health professionals have the necessary information to understand the difference between the public and private banks and even fewer health professionals have adequate information education time to provide citizens with independent and accurate information necessary to ensure informed consent for stem cells storage.

The cost impact of the stem cell therapy is likely to be high, because of a therapy's high cost per patient, and the potentially large number of individuals who might benefit from the therapy. This expense would put additional stress on the Medicare and Medicaid budgets, cause private insurance health premiums to increase, and create an incentive for private plans to avoid covering individuals eligible for a therapy." (13) Findings of the present study represented that, nurses had a consider able attitude regarding the barriers in seeking stem cells treatment. About half of them reported that the stem cells transplantation barriers represent high cost.

On the base of this study barriers were, from then urses' point of view is the cost of initiation of such high standardized unit takes the greatest priority. It also requires that umbilical cord blood banks establishments are inspected and accredited by a Competent Authority. Other mentioned barriers perceived by then urses is the hospital policy and lacking of the time which needed to educate the nurses. The time needed for educating is an avoidable barrier while all nurses in such places underwent planned training courses in the required subjects periodically and as needed. These findings are nearly similar with study of Abdulla et.al,(14 )

In their study to know what nurses and health care providers should know, they found that from the healthcare providers' point of view the greatest barrier could be the time to educate the patient. Information given to the patients can be misinterpreted, misunderstood, or miss-communicated. The thoroughness of 
education provided to the patient is critical to the outcome, and yet the time to provide such education is not always available.

These results are consistent with the results of Hollands P. \& Caule C. (2009), The cost impact of the therapy is likely to be high, because of a therapy's high cost per patient, and the potentially large number of individuals who might benefit from the therapy. The financial impact could be lessened if the therapies generate health care cost savings by curing diseases and disabilities that are expensive to treat $(15)$.

Regarding the relationship between the total nurses' knowledge about the stem cells and the sociodemographic characteristics, the present study revealed that, there was statistical significant correlation between PICU nurses' total awareness and attitude with their age as when the age increase the nurses knowledge will in turn increase. This could be because nurses of this middle age have different priorities and interests such as postgraduate studying and looking for occupation rather than starting a family and having children. Study is similar with the present study results which was done by Karagiorgous et al,(16) to assess the knowledge about stem cells banking among Greece citizens and they found that, respondents aged between 18-27 years old seemed to be less informed about the subject of stem cells compared to respondents of other age groups.

Furthermore, the current study revealed that there was no statistical significant correlation between nurses' knowledge, awareness, attitude and education in both setting. These findings are in disagreement with the results in other countries like Dinc \& Sahin, (17) who study the nurses' knowledge and attitude about stem cells banking and they found that there is a strong positive correlation between the educational level and the knowledge of stem cells.

\section{Conclusion}

Nurses knowledge and awareness about stem cells was poor from the scientific evidence to support the practice that permits the conduction of such unit in their hospitals .on the other hand, the nurses attitude towards stem cells was positive as the majority of them agree to attend work shop about stem cell.

\section{Recommendations}

- Educational course and continual training about the use of stem cells and the potential benefits of stem cells banking must be implemented for then urses in paediatrics' Health Hospitals, Tanta University, Egypt.

- Stem cell topic must be included in nursing curriculum at nursing schools and faculties.

- The Ministry of Health should play a more role in giving updated an devidence- based information about stem cells to the population and informs their environment on its uses particularly it is an important source of hematopoietic stem cells. Initiation of such banks should be according to the approved standards and parents and care providers understanding the differences between auto log us versus allogenic donation and private versus. Public banks.

\section{References}

[1]. Bhattacharya N, Mukherijee K, Chettri MK, Banerjee T, Mani U, Bhattacharya S. A study report of 174 units of placental umbilical cord whole blood transfusion in 62 patients as a rich source of fetalhemoglobin supply in different indications of blood transfusion. Clin Exp Obstet Gynecol 2001; 28 : 47-52.

[2]. Madhavan A. Umbilical cord blood banking. [online]. [cited 2015 Nov 29]; Available from: URL:http://www.stemcellresearchfoundation.org.

[3]. International Stem Cell Services Ltd. Banking on stem cells. [online]. [cited 2015 Nov29]; Available from: $\underline{\text { URL: }}$ http://www.internationalstemcelllcervices.com

[4]. Ian Murnaghan for Explore Stem Cells. Why Perform a Stem Cell Transplant? Updated: 16 December 2013.

[5]. Bethesda, MD. Bone Marrow Transplantation and Peripheral Blood Stem Cell Transplantation In National Cancer Institute Fact Sheet web site.: National Institutes of Health, U.S. Department of Health and Human Services, 2010. Cited 24 August 2015

[6]. Oulton. J.A, The International Council of Nursing Code of Ethics for Nurses( ICN). International Nursing Review journal;2000,47(3), $138-141$

[7]. Yildirim G.\&, N.H, Sahin. Stem cell transplantation and nursing approach. Istanbul University, Florence Nightingale Nursing Academy. Nursing Journal; 2007, 60(15), ,25-31.

[8]. Rosemann A. "Why regenerative stem cell medicine progresses slower than expected". Cell BiochemJournal2014; 115 (12): 2073-6.

[9]. National MS Society. Results Reported from Case Studies of Stem Cell Transplantation in People with Relapsing and Progressive MS". January 2015.

[10]. Hatzistilli H., Zissimopoulou O., GalanisP., Perzerakos.P, ZissimopolousA., and Kaitelidou D. Health professionals' knowledge andattitude towards the umbilical cord blood donation in Greece. Hippokaratia; 2014 Apr-Jun.;1 $8(2): 110-115$.

[11]. KatzG.,MillsA., GarciaJ., HooperK., Mc Guckin Cand Platz, A..Banking cord blood stem cells: attitude and knowledge ofpregnantwomeninfiveEuropecountries.Transfusion.2011;51:578-86.[PubMed]. 
[12]. Screnci M.,Murgi E.,Pirre G.,Valende E.,GesuitE. And Corona, F. Do nating umbilical cord blood to a public or storing it in a private bank: knowledge and preferences of blood on ors and pregnant women. Blood Transfs journal .2012;10:331-337.[PubMed].

[13]. Francis, DP; Mielewczik, M; Zargaran, D; Cole, GD. "Autologous bone marrow-derived stem cell therapy in heart disease: Discrepancies and contradictions". International journal of cardiology. 2013;168 (4): 3381-403.

[14]. Abdullah,Y. Cord blood banking; what nurses and health care providers should know, The American Journal of Maternal and Child Nursing; 2011,36(6),344-350.[PubMed].

[15]. HollandsP., CauleC. Private cord blood banking: current use and clinical.CellRev.;2009,5(3):195-203.[PubMed].

[16]. .KaragiorgouL. Z,. Panta zopoulou M.P, MainasN.C,.v Beloukas A.I, and Kriebardis, A.G. Knowledge about umbilical cord blood banking among Greekcitizens. Blood Tranfus;2014,.Jan;12 (Suppl1):s353-s360.

[17]. Dinc, H., ,SahinN.H. Pregnant women's Knowledge and attitudes about stem cells and cord blood banking. International Nursing Review journal; 2009, 56(2) ,2009,250-256. 